\title{
Evaluation and development of a bone age assessment method in patients with Down syndrome
}

\section{Avaliação e desenvolvimento de um método de verificação de idade óssea em portadores de síndrome de Down}

\section{Michelle Bianchi de MORAES}

Ph.D - Department of Oral Diagnosis and Surgery - School of Dentistry of São José dos Campos - UNESP

- Univ Estadual Paulista - São José dos Campos - SP - Brazil.

\section{Mari Eli Leonelli de MORAES}

$\mathrm{PhD}$ - Associate Professor - Department of Oral Diagnosis and Surgery - School of Dentistry of São José dos Campos - UNESP - Univ Estadual Paulista - São José dos Campos - SP - Brazil.

\section{Fernando Vagner RALDI}

$\mathrm{PhD}$ - Professor - Department of Oral Diagnosis and Surgery - School of Dentistry of São José dos Campos

- UNESP - Univ Estadual Paulista - São José dos Campos - SP - Brazil.

\section{Simone Maria Ragone GUIMARÃES}

MS, Ph.D. - Department of Oral Diagnosis and Surgery - School of Dentistry of São José dos Campos UNESP - Univ Estadual Paulista - São José dos Campos - SP - Brazil.

\section{Déborah HOLLEBEN}

Graduate student - Department of Oral Diagnosis and Surgery - School of Dentistry of São José dos Campos

- UNESP - Univ Estadual Paulista - São José dos Campos - SP - Brazil.

\begin{abstract}
This study evaluated the applicability of the method developed by Caldas to measure vertebral bone age for Brazilians suffering from Down syndrome. A database comprised of 57 case records of individuals with this syndrome, both male and female, with age ranging between 5 and 18 years, was assessed. These records had lateral cefalometric radiographies and radiographies of hand and wrist, being all obtained on the same date. Also, 48 records of individuals not suffering from Down syndrome were assessed. For the hand and wrist radiographies the Tanner and Whitehouse (TW3) method was used, and bone age was obtained. The Caldas method was employed on the lateral cefalometric radiographies in order to obtain the vertebral bone age. From the information about the bone age, vertebral bone age and chronological age, the Wilcoxon test was used to compare all the ages in pairs. There was a statistically significant difference between the three ages mentioned above for both male and female control group and female Down syndrome group. Therefore, this method was only suitable for Down syndrome male individuals. Based on the results, a formula to obtain the bone age for Down syndrome individuals was developed.
\end{abstract}

\section{KEYWORDS}

Down syndrome; bone development; cervical vertebrae; growth; radiology. 


\section{INTRODUCTION}

The Down syndrome is characterized by mental deficiency and innumerous physical anomalies caused by the chromosome 21 trisomy. In 1866, Langdon Down first described the characteristics of individuals with the chromosome 21 trisomy and named it Mongolian idiot, which was soon in disused fulfilling a recommendation of the World Health Organization (WHO). Later, it was renamed Down Syndrome [1]

Santos [2] used in his work 85 X-rays of 52 male and 33 female individuals, all of them suffering from Down syndrome. He evaluated the Greulich and Pyle [3], Eklöf and Ringert [4] or Tanner and Whitehouse [5] methods in order to evaluate their accuracy of determining the chronological age in Down syndrome individuals aged between 61 and 180 months by using hand and wrist X-rays. According to this research, the TW3 and Greulich and Pyle methods came closest to the chronological ages, followed by the Eklöf and Rigertz approach $[3,4]$.

Mito et al. [6] also elaborated a new method to evaluate specifically the bone maturation using lateral cefalometric X-rays. It was stated that the correlation between the bone age obtained by the hand and wrist radiographs and the cervical vertebrae maturation was statistically significant [6]. The difference between bone ages was not detected in comparison to the chronological age. It was concluded that, if the objective is to obtain the bone age by the cervical vertebrae, the study with detailed cefalometric X-ray is viable.

Caldas [7] evaluated the applicability of the bone age analysis method of the cervical vertebrae developed by Mito et al. [6] in females with Japanese background in the Brazilian population. She also elaborated two new methods for Brazilian girls and boys, with the intention to determine the bone maturation of the cervical vertebrae in a straightforward way in lateral cefalometric X-rays [7]. The bone age was used as a golden pattern to determine the reliability of the Mito method. The results obtained showed that there was a statistically significant difference between the vertebral and chronological ages and between the bone age and the chronological age for the female population [8]. The derivation of a formula for Brazilian boys and girls concerning an objective analysis of the bone maturation of the cervical vertebrae revealed that there is no statistical difference between the bone age of the cervical vertebrae, the bone age, and the chronological age [7]. Therefore, it was concluded that the Mito method can be applied only to Brazilian girls $[6,7]$. In addition, the derived formulae for objective evaluation of the bone age of the cervical vertebrae can be applied to Brazilian boys and girls in an efficient manner [7].

\section{Material and Method}

After being approved by the Committee of Ethics in Researches under number 018/2007-PH/CEP, 105 cases were selected for study from the files of the Discipline of Radiology of the Department of Diagnosis and Surgery of the Faculdade de Odontologia São José dos Campos, Universidade Estadual Paulista "Júlio de Mesquita Filho" - UNESP. These cases were divided into 2 groups:

- Group Down: 57 cases of Down syndrome, being 23 females and 34 males.

- Group Control: 48 cases of non Down syndrome, being 24 females and 24 males.

Both groups were comprised of individuals with age ranging from 5 to 18 years, who had lateral cefalometric $\mathrm{X}$-rays and hand and wrist X-rays obtained on same dates.

Lateral cefalometric X-rays were used to analyze the vertebral bone age of the individuals through the method proposed by Caldas [7], which was derived from Brazilian individuals, both female and male, who did not suffer from Down syndrome.

This method consists on one formula for males and another for females, all of which use a mathematical ratio obtained by the measurement of the variables of the bodies of the cervical vertebrae $\mathrm{C} 3$ and $\mathrm{C} 4$ for the obtaining of the bone vertebral age of each individual.

- Female vertebral bone age $=1.3523+6.7691$ $\mathrm{x} \mathrm{AH} 3 / \mathrm{AP} 3+8.6408 \times \mathrm{AH} 4 / \mathrm{AP} 4$

- Male vertebral bone age $=1.4892+11.3736$ $\mathrm{x} \mathrm{AH} 3 / \mathrm{AP} 3+4.8726 \times \mathrm{H} 4 / \mathrm{AP} 4$

From both cervical vertebrae, it was obtained the variables: $(\mathrm{AH})$ anterior height of the vertebral body, (AP) lateral anterior-posterior of the vertebral body and $(\mathrm{H})$ the height of the vertebral body, $(\mathrm{PH})$ posterior height of the vertebral body. Those variables were named AH3, AP3, H3, PH3 when they referred to the cervical vertebra $\mathrm{C} 3$; and $\mathrm{AH} 4, \mathrm{AP} 4, \mathrm{H} 4, \mathrm{PH} 4$ when referred to $\mathrm{C} 4$ (Figure 1). 


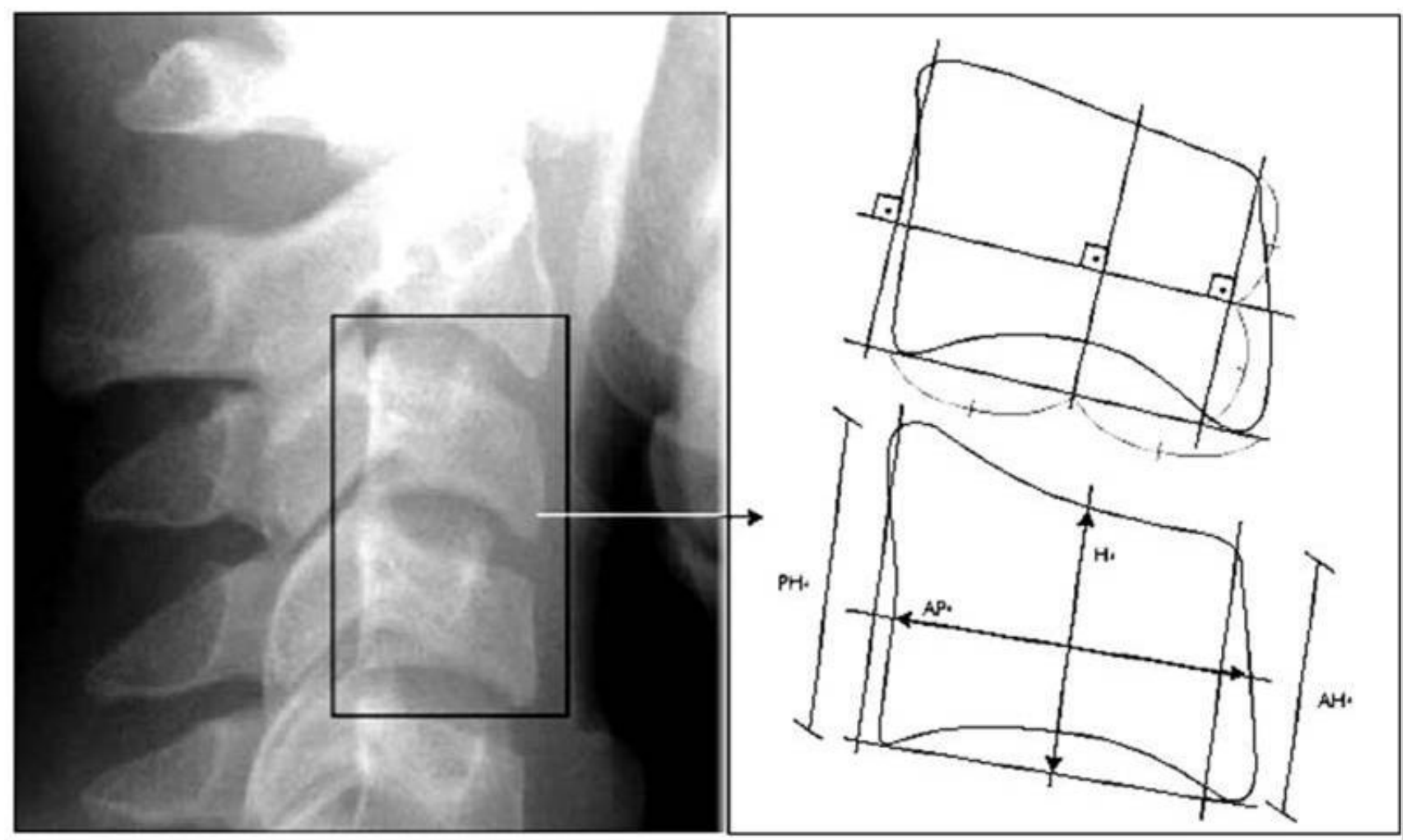

Figure 1: Body of cervical vertebrae $\mathrm{C} 3$ and $\mathrm{C} 4$ measured by means of side cefalometric $\mathrm{x}$-rays: $(\mathrm{AH})$ anterior height of the vertebral body, (AP) lateral anterior-posterior of the vertebral body and $(\mathrm{H})$ the height of the vertebral body, $(\mathrm{PH})$ posterior height of the vertebral body.

The vertebrae $\mathrm{C} 3$ and $\mathrm{C} 4$ segments were scratched manually and measured through a milimetric ruler and a digital caliper. Two repetitions of the scratch were randomly made with the interval of one week. The intention was to obtain an average between the measurements obtained in each radiographic incidence and they were named vertebral age 1 and 2 for the Down syndrome individuals. The method proposed by Tanner and Whitehouse [8], TW3, was used to obtain the bone age using hand and wrist X-rays of the same individual. All the measurements were done by only one previously trained examiner (author of this paper).

\section{Results}

In this research, the authors chose non-parametric statistical tests which do not compare groups by the average but by the position of the data. Even though the mean values were not used for comparisons, the descriptive statistic analysis was used to interpret the results, which can be seen in non Down syndrome individuals. In this group, for both male and female individuals, we observed the existence of significant statistical differences among the ages in a general manner. This way, we used the Wilcoxon test to compare all ages in pairs in order to precisely assess where differences occurred (Table 1).

TABLE I - P-VALUES, FOR NON DOWN SYNDROME INDIVIDUALS, CHRONOLOGICAL, BONE AND VERTEBRAL AGE FOR MALE AND FEMALE

\begin{tabular}{c|c|c|c}
\hline & $\begin{array}{c}\text { Non Down } \\
\text { Syndrome }\end{array}$ & Chronological & Bone \\
\hline Male & Bone & 0.367 & \\
\hline & Vertebral & 0.042 & $<0.001$ \\
\hline Female & Bone & 0.788 & \\
\hline & Vertebral & 0.048 & 0.037 \\
\hline
\end{tabular}

Regarding the p-values, it was noticed that there is a significant statistical difference among the vertebral bone age, the bone age, and the chronological age. In the studied sample, for both male and female individuals, the vertebral bone age presented higher values than all the remaining ones.

The results of the comparison among all the ages for the group of Down syndrome individuals are presented next. In this group, significant statistical differences among the ages for the female individuals (Table 2) could be noticed. 
TABLE 2 - P-VAlues, for Down syndrome INDIVIDUALS, CHRONOLOGICAL, BONE, VERTEBRAL, AND VERTEBRAL 1 AGE FOR FEMALE

\begin{tabular}{c|c|c|c|c}
\hline & $\begin{array}{c}\text { Down } \\
\text { Syndrome }\end{array}$ & Chronological & Bone & Vertebral 1 \\
\hline Female & Bone & 0.308 & & \\
\hline & Vertebral & 0.287 & 0.114 & \\
\hline & Vertebral & 0.073 & 0.039 & 0.046 \\
\hline
\end{tabular}

According to the observed p-values, the differences occurring between the vertebral age 2 and the vertebral age 1 were revealed. The vertebral age 2 is the one which has the higher values when compared to the other ages. Thus, in this sample of the female group of Down syndrome individuals the formula derived by Caldas [7] was not applied (Figures 1 and 2).

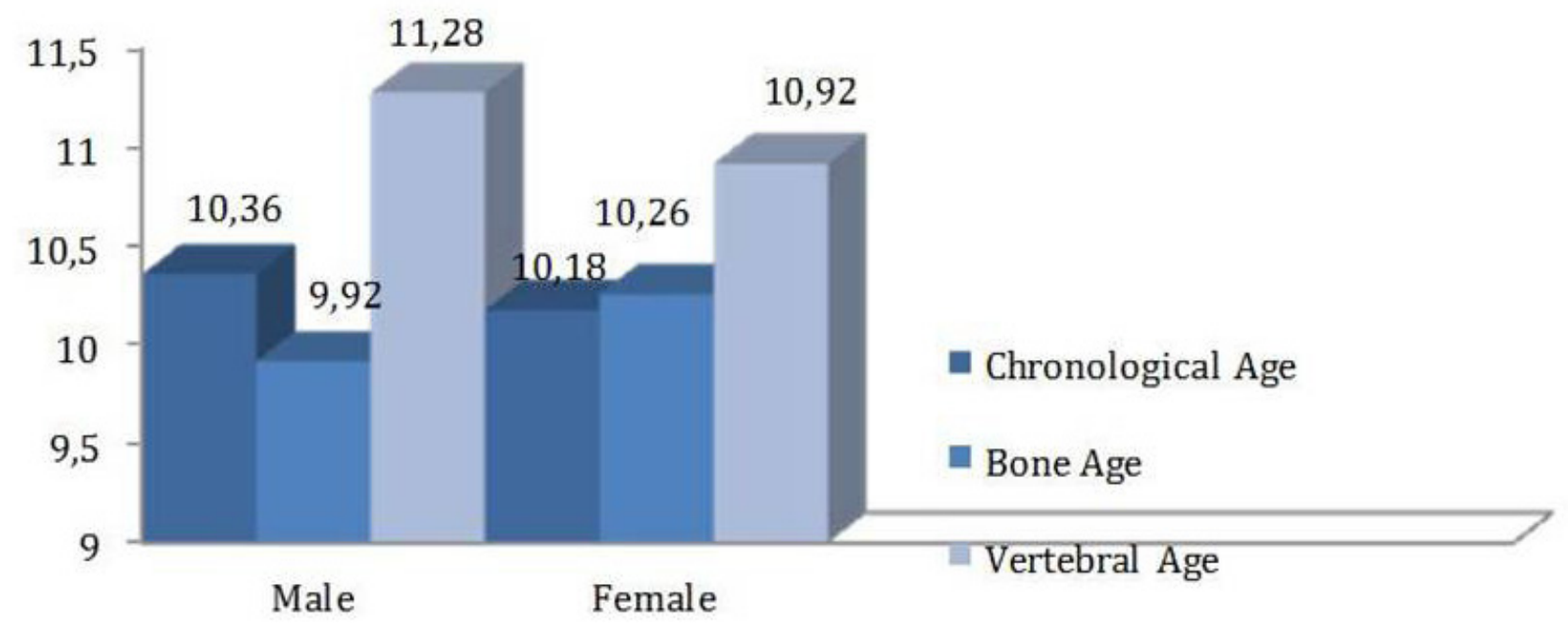

Figure 2 - Comparison of the chronological, vertebral bone and bone age for non Down syndrome individuals male and female.

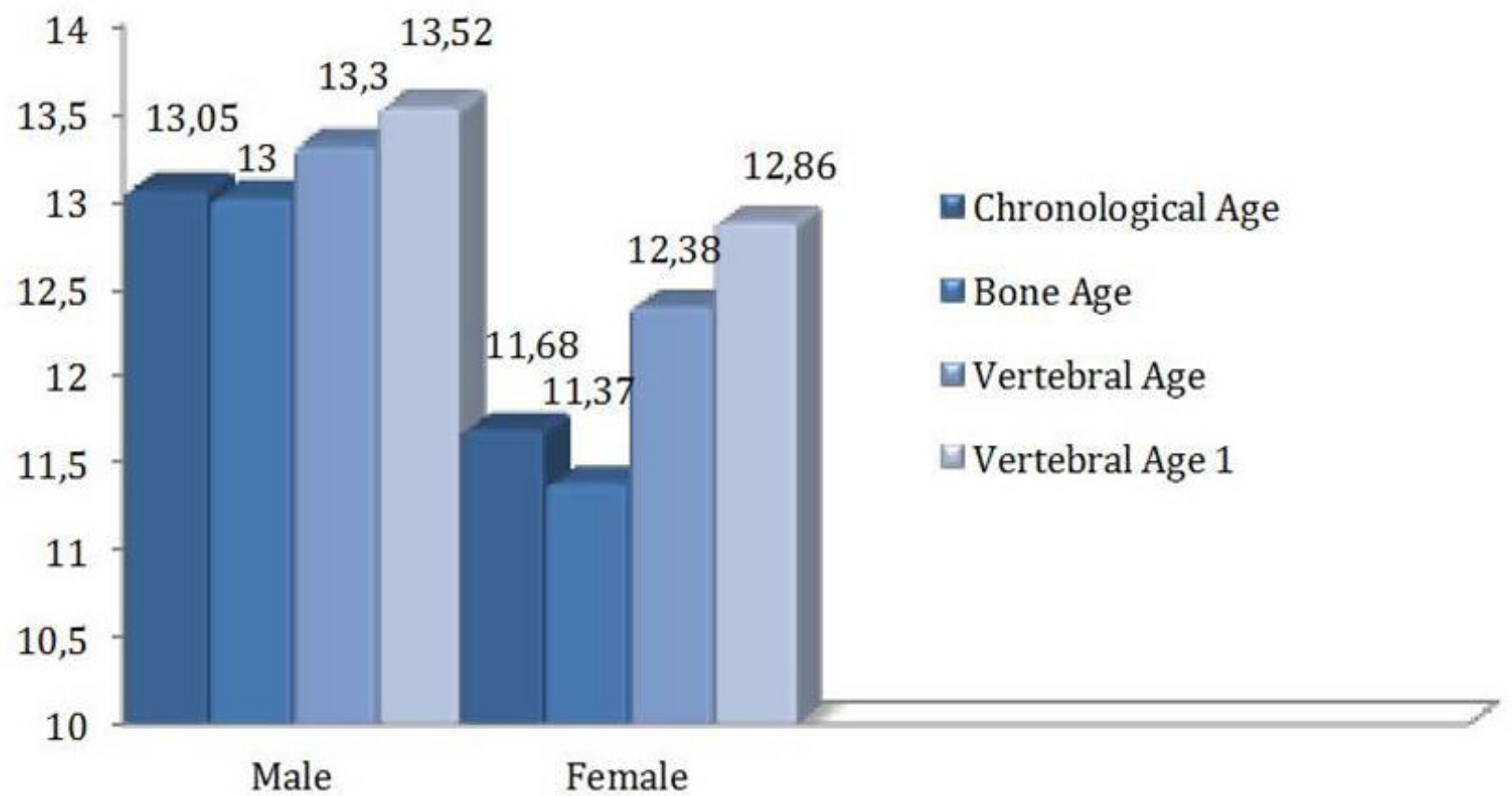

Figure 3 - Comparison of the chronological, vertebral bone 1 and bone 1 age in Down syndrome individuals male and female. 
For the Down syndrome individuals of the male group significant statistical differences among the ages were not observed, so that the formula by Caldas [7] can be applied.

Based on these results we can address the description of the method for bone age in Down syndrome individuals.

- Female vertebral bone age $=-2.364+1.441-\mathrm{H} 3$ $\mathrm{R} 2=84.2 \%$

- Male vertebral bone age $=-1.004+0.759 \times$ $\mathrm{H} 3+0.580 \times \mathrm{AH} 4$

$\mathrm{R} 2=84.1 \%$

\section{Discussion}

After applying three methods to estimate the bone age in Down syndrome individuals, Santos [8] noticed statistical differences only in the Eklöf and Ringertz method, when it refers to the sex and chronological age [4]. The methods TW3 and Greulich and Pyle were statistically the same between them $[3,8]$. In relation to the Eklöf and Ringertz [4] method in Down syndrome individuals, Sannomiya et al. [9] made the same observation, but did not find significant statistical differences among the sexes.

Calles et al. [10] observed that, in Down syndrome individuals, the method of Greulich and Pyle [3] is used, but it is not indicated for the chronological ages between 10 and 13 years old for the female group and between 13 and 15 years old for the male group. They concluded that in these age groups there was a significant statistical difference when analyzing the chronological and bone ages [10]. Sannomiya et al. [4] came to the same conclusion, which is the reason why the authors preferred to adopt the TW3 method in this study, which is also more updated.

Mito et al. [6], using lateral cefalometric X-rays of Japanese individuals created a formula with the measurements of vertebral $\mathrm{C} 3$ and $\mathrm{C} 4$ bodies to obtain the bone age by the cervical vertebrae of those individuals. They concluded that this result can be trusted when compared to others obtained by the hand and wrists X-ray through the TW2 method [5,6] In 2007, Caldas [7] applied the Mito et al. [6] formula in female and male Brazilians, and observed that it was only applicable to the Brazilian girls. Therefore she created a formula to analyze the skeleton maturation of the cervical vertebrae in Brazilian boys and girls [7].

In this study, the authors applied the Caldas [7] formula created for female and male Brazilians to non Down syndrome individuals, and the result was different from the author's, because the created formula was not statistically significant for the sample studied. Also, when applied to the Down syndrome individuals sample, it was significant statistically only for the male group, but not for the female one.

With the results obtained it was possible to prove the non applicability of the formula created for Brazilian boys and girls by Caldas [7] to the female Down syndrome individuals of the studied sample. Thus, two new formulae were obtained, one for women and another for men using the statistical method.

We could verify that both models were significant and very explanatory, which means they were well correlated with reference to the value of R2 (the closer the value 1 , the more significant is the value of formula). We verified that the model is applicable, because there is no significant statistical difference between the bone age value (obtained by the TW3) and the final bone age calculated through the model developed in this research.

In this context, it is worth mentioning that there is a difference between the final bone ages and the vertebral bone age only for the female group. The index for the bone age for the Down syndrome individuals does not have a specific method for verification.

\section{Conclusion}

Due to the findings of this study some important considerations can be made:

- The method proposed by Caldas [7], when applied to our samples of female and male non Down syndrome individuals, showed results with a significant statistical difference between the bone, vertebral bone, and chronological ages.

- Thus, a similar method of evaluation for bone, vertebral bone age for Down syndrome individuals, both male and female has been developed. 


\section{Resumo}

Este estudo avaliou a aplicabilidade do método desenvolvido por Caldas para medir a idade óssea vertebral em brasileiros, quando empregada em indivíduos portadores da síndrome de Down. Foram estudados 57 prontuários de indivíduos com síndrome de Down, de ambos os sexos, com idade variando entre 5 e 18 anos. Estes prontuários continham radiografias cefalométricas laterais e radiografias de mão e punho, obtidos no mesmo dia, e também foram avaliados 48 prontuários de indivíduos não portadores de síndrome de Down. Para as radiografias de mão e punho o método de Tanner e Whitehouse (TW3) foi usado para que pudéssemos obter a idade óssea. O método de Caldas foi empregado nas radiografias cefalométricas laterais, e assim obtivemos a idade óssea vertebral. A partir das informações sobre a idade óssea, idade óssea vertebral e idade cronológica, utilizou-se o teste de Wilcoxon para comparar todas as idades aos pares o qual mostrou uma diferença estatisticamente significativa entre estas três idades citadas acima para ambos os sexos do grupo controle e grupo com síndrome de Down do sexo feminino. Portanto, este método foi aplicável apenas em indivíduos do sexo masculino portadores da síndrome de Down. Com base nos resultados uma fórmula para obtenção da idade óssea de indivíduos com síndrome de Down foi desenvolvida.

\section{Palavras-chave}

Síndrome de Down; desenvolvimento ósseo; vértebras cervicais; crescimento; radiologia.

\section{REFERENCES}

1. Coelho CRS, Loevy HT. Aspectos odontológicos da síndrome de Down. Ars Curandi Odontol.1982;8(3):9-16.

2. Santos LRA. Análise comparativa entre três métodos de estimativa da idade óssea em indivíduos com síndrome de Down, por meio de radiografias de mão e punho [tese]. São José dos Campos: Faculdade de Odontologia de São José dos Campos, Universidade Estadual Paulista; 2007.

3. Greulich WW, Pyle SI. Radiographic atlas of skeletal development of the hand and wrist. Stanford: Stanford University Press; 1959.

4. Sannomiya EK, Calles A. Comparação da idade óssea com a cronológica em indivíduos portadores da síndrome de Down pelo índice de Eklöf \& Ringertz, por meio de radiografias de mão e punho. Cienc Odontol Bras. 2005;8(2):39-44.

5. Tanner JM, Whitehouse RH, Cameron N. Assessment of skeletal maturity and prediction of adult height (TW2 Method). London: Academic Press; 1983.

6. Mito T, Sato K, Mitani H. Cervical vertebral bone age in girls. Am J Orthod Dentofac Orthop. 2002;122(4):380-85.

7. Caldas MP. Avaliação da maturação esquelética na população brasileira por meio da análise das vértebras cervicais [dissertação]. Piracicaba: Faculdade de Odontologia de Piracicaba, Universidade Estadual de Campinas; 2007.

8. Tanner JM, Whitehouse RH, Cameron N, Healy MJR, Goldstein $\mathrm{H}$. Assessment of skeletal maturity and prediction of adult height (TW3 Method). Austral Radiol. 2003;47:34041.

9. Sannomiya EK, Médici-Filho E, Castilho JCM, Graziosi MAOC. Avaliação da idade óssea em indivíduos portadores da síndrome de Down por meio de radiografias da mão e punho. Rev. Odontol. Unesp.1998;27(2):527-36.

10. Calles AC, Carinhena G. Avaliação da idade óssea em indivíduos portadores da síndrome de Down por meio de radiografias da mão e punho. [texto de internet]. Acesso em mar.2008. Disponível em: HTTP: // www.cleber.com.br/ orto2004/andreia.html
Received: 08/05/2012

Accepted: 28/08/2012

Corresponding author: Michelle Bianchi de Moraes Departamento de Diagnóstico e Cirurgia- Faculdade de Odontologia São José dos Campos, Universidade Estadual Paulista "Júlio de Mesquita Filho"-UNESP. Eng. Francisco José Longo, $n^{\circ}$ 777- Jardim São

Dimas/ CEP: 12245-000 São José dos Campos, SP, Brasil. Tel: (12) 39479043 mickbianchi@hotmail.com 